\title{
Syntheses and characterization of phthalonitriles and phthalocyanines substituted with adamantane moieties ${ }^{1}$
}

\author{
Patrick W. Causey, Igor Dubovyk, and Clifford C. Leznoff
}

\begin{abstract}
The reaction of 3,4,5,6-tetrafluorophthalonitrile with 1-adamantanol, 1-adamantylamine, 1-adamantanemethanol, and 1-adamantaneethanol gave 4,5-di-(1-adamantyloxy)-3,6-difluorophthalonitrile, 4,5-di-(1-adamantylamino)-3,6difluorophthalonitrile, 4-(1-adamantylamino)-3,5,6-trifluorophthalonitrile, 3,4,5,6-tetra-(1-adamantylmethoxy)phthalonitrile, and 3,4,5,6-tetra-(1-adamantylethoxy)phthalonitrile, respectively. The conversion of these tetrasubstituted phthalonitriles to magnesium, nickel, and metal-free phthalocyanines was demonstrated. These highly hindered phthalocyanines exhibited interesting red shifts in their UV-vis spectra.
\end{abstract}

Key words: highly hindered adamantane phthalocyanines, adamantylphthalonitriles.

Résumé : La réaction du 3,4,5,6-tétrafluorophtalonitrile avec l'adamantan-1-ol, l'adamantyl-1-amine, l'adamantane-1méthanol et l'adamantane-1-éthanol conduit à la formation des 4,5-di-(adamantanyl-1-oxy)-3,6-difluorophtalonitrile, 4,5di-(adamantanyl-1-amino)-3,6-difluorophtalonitrile, 4-(adamantanyl-1-amino)-3,5,6-trifluorophtalonitrile, 3,4,5,6-tétra(adamantanyl-1-méthoxy)phtalonitrile, 3,4,5,6-tétra-(adamantanyl-1-éthoxy)phtalonitrile respectivement. On a démontré qu'il est possible de transformer ces phtalonitriles tétrasusbstitués en phtalocyanines libre ou complexées avec du nickel ou du magnésium. Les spectres UV-visible de ces phtalocyanines fortement empêchées présentent des déplacements intéressants vers le rouge.

Mots clés : phtalocyanines de l'adamantane fortement empêchées, adamantylphtalonitriles.

[Traduit par la Rédaction]

\section{Introduction}

Phthalocyanines (Pcs) are brilliantly coloured purple, blue, or green macrocyclic compounds that have been extensively studied, initially because of their extensive use as dyes (1), but more recently because of their interesting photochemistry (2), potential applications as chemical sensors (3), nonlinear optics (4), and as medicinal agents in photodynamic therapy (PDT) (5). Recently, red-coloured manganese Pcs for analogs, substituted with highly hindered, bulky hexadecaalkoxyl functional groups, have been reported $(6,7)$, while other red phthalocyanines bearing alkylthio (8) and phenyl groups (9) have been described. These analogs represent Pcs exhibiting pronounced red shifts. Previously, some highly red-shifted analogs of some Pcs had been prepared with some difficulty owing to insolubility (10) and decomposition problems (11).

A significant bathochromic red shift of the Pc chromophore has long been associated with analogs bearing electron-donating substituents at the $1,4,8,11,15,18,22$, and 25 positions (nonperipheral), while less pronounced red shifts of the $Q$ band are associated with substitution on the
$2,3,9,10,16,17,23$, and 24 positions (peripheral) $(12,13)$. For analogs fully substituted at both the peripheral and nonperipheral positions with alkoxy moieties, enhanced red shifts of the $Q$ band have also been reported (14). It has been postulated that sterically bulky substituents at the peripheral positions around the Pc exert influence upon the nonperipheral positions, thereby effectively increasing the steric bulk of the nonperipheral substituents and further promoting a shifting of the $Q$ band. Various metallated and nonmetallated Pcs bearing sterically bulky alkoxy moieties have been reported, including both neopentoxy and cyclohexylmethoxy groups $(6,7)$. In addition to the effect that these substitutions appear to have on the absorption spectra of the resulting Pcs, a disruption of the $\pi$ stacking among the aromatic macrocycles increases the solubility of the molecule, even in nonpolar solvents.

One particular bulky alkyl moiety that has interested our research group is adamantane. In particular, aminesubstituted adamantanes have been approved for treatment as an antiviral agent against influenza $A$ (15) and adamantyl moieties have been investigated for their potential use as carrier groups for anticonvulsant (16) and anticancer drugs 
Scheme 1. Reagents and conditions: (i) $n$-BuLi, THF, $25^{\circ} \mathrm{C}, 1 \mathrm{~h}$; (ii) $\mathrm{K}_{2} \mathrm{CO}_{3}$, DMF, $140{ }^{\circ} \mathrm{C}, 4$ days.

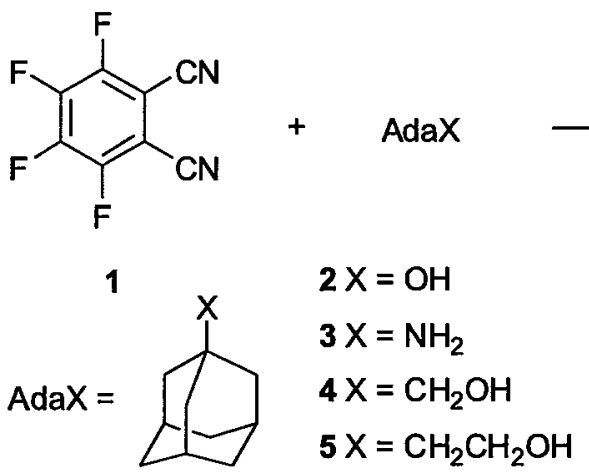

(17). However, it is their more general physicochemical characteristics associated with large steric bulk and their close steric relationship to our favorite bulky group, the neopentoxy group, that have piqued our interest as related to the potential for substitution onto the Pc framework.

The synthesis of substituted Pcs can be accomplished through two distinct approaches, each involving nucleophilic aromatic substitution. A recent approach employed in our research group has focused upon directly reacting metallated hexadecafluorophthalocyanines with various heteroatom nucleophiles (18). A limit to this synthetic approach is the distribution of substituents replacing the fluorine atoms resulting in a range of products that are difficult to separate by flash chromatography. Furthermore, complete replacement of all 16 fluorine atoms is limited to sterically small, strong nucleophiles Alternatively, tetrasubstituted phthalonitriles bearing functionalities, such as the neopentoxy group, can be readily produced by nucleophilic aromatic substitution reactions on 3,4,5,6-tetrafluorophthalonitrile (1) despite the steric bulk of the substituents (19).

The general synthetic strategy employed for the synthesis of adamantyl-substituted Pcs follows the production and isolation of substituted phthalonitriles. Subsequent condensation of the adamantyl-substituted phthalonitriles gives the required phthalocyanines. In this research we were interested in systematically varying the bulk of the substitiuents so as to produce a series of hexadecasubstituted phthalocyanines and examining their spectroscopic properties.

\section{Results and discussion}

A novel series of phthalocyanine compounds were designed and synthesized bearing bulky adamantane-based substituents. Commercially available 3,4,5,6-tetrafluorophthalonitrile (1) was reacted with 1-adamantanol (2), 1adamantylamine (3), 1-adamantanemethanol (4), or 2-(1adamantanyl)ethanol (5) in the presence of a base to generate 4,5-di-(1-adamantyloxy)-3,6-difluorophthalonitrile (6), 4,5-di-(1-adamantylamino)-3,6-difluorophthalonitrile (7), 4(1-adamantylamino)-3,5,6-trifluorophthalonitrile (8), 3,4,5,6tetra-(1-adamantylmethoxy)phthalonitrile (9), or $3,4,5,6$ tetra-[2-(1-adamantyl)ethoxy]phthalonitrile (10). For the synthesis of fully substituted adamantylmethoxyl and adamantylethoxyl (Scheme 1) derivatives, a previously re-<smiles>[R]c1c([R])c([R])c(C#N)c([R])c1[R]</smiles>

$$
\begin{aligned}
6 \mathrm{R} & =\mathrm{R}^{\prime \prime}=\mathrm{OAda}, \mathrm{R}^{\prime}=\mathrm{F} \\
7 \mathrm{R} & =\mathrm{R}^{\prime \prime}=\mathrm{NHAda}, \mathrm{R}^{\prime}=\mathrm{F} \\
8 \mathrm{R} & =\mathrm{NHAda}, \mathrm{R}^{\prime}=\mathrm{R}^{\prime \prime}=\mathrm{F} \\
9 \mathrm{R} & =\mathrm{R}^{\prime}=\mathrm{R}^{\prime \prime}=\mathrm{OCH}_{2} \text { Ada } \\
10 \mathrm{R} & =\mathrm{R}^{\prime}=\mathrm{R}^{\prime \prime}=\mathrm{OCH}_{2} \mathrm{CH}_{2} \text { Ada }
\end{aligned}
$$

ported synthetic approach was followed in which an excess of alkyl alcohol was combined with 3,4,5,6-tetrafluorophthaIonitrile (1) in $N, N$-dimethylformamide (DMF) at $140^{\circ} \mathrm{C}$ in the presence of potassium carbonate (19). Both tetrasubstituted crude products, purified by flash silica gel column chromatography, were eluted with dichloromethane-methanol and reduced to an amber-coloured oil under reduced pressure. These oils solidified under a stream of air yielding the desired final products, which were confirmed by EI mass spectra NMR and IR spectroscopic analysis and microanalyses.

Despite repeated attempts to synthesize the tetrasubstituted analog from 1-adamantanol and 1 using this synthetic approach, the reaction was not successful. Therefore, an alternative synthetic approach for the aromatic nucleophilic substitution of the phthalonitrile fluorine was implemented, in which $n$-butyllithium in tetrahydrofuran (THF) was used to deprotonate 2 (or 3) to create the desired nucleophile. Although this modified approach did result in fluorine substitution, complete tetrasubstitution was not achieved, presumably because of the high degree of steric bulk associated with the adamantanyl cage. This steric hindrance is not so severe in the adamantanemethanol and adamantaneethanol homologs, thereby enabling complete substitution. An obvious colour change was noted immediately upon addition of 3,4,5,6-tetrafluorophthalonitrile to the activated adamantyloxide nucleophile, and despite allowing the reaction to continue for up to $72 \mathrm{~h}$, substitution of more than two fluorine moieties was not observed (Scheme 1). TLC of the reaction mixture did reveal an additional spot that was presumed to be the monosubstituted analog, although isolation of this species was not achieved. As usual, a sharp intense absorbance at $2239 \mathrm{~cm}^{-1}$ was observed in the IR spectra and was attributed to $\mathrm{CN}$ stretching. Furthermore, EI mass spectroscopy and microanalysis confirmed that the product from this reaction is a disubstituted phthalonitrile. The ${ }^{1} \mathrm{H}$ NMR spectra for this compound revealed the expected resonances for the adamantyl protons between $\delta 1.68$ and $2.24 \mathrm{ppm}$, while the ${ }^{19} \mathrm{~F}$ NMR exhibited a singlet at $\delta-114.9 \mathrm{ppm}$. The singlet suggests that the two adamantyloxy substituents are positioned at the peripheral position.

The synthesis of derivatives substituted with nitrogencontaining adamantane analogs was accomplished through an approach similar to adamantanol involving the in situ 
generation of an adamantamide anion from 3, followed by subsequent addition of 1 . The desired disubstituted product was separated by flash silica gel column chromatography, yielding an amber-coloured oil that solidified under air. EI mass spectroscopy and elemental analysis confirmed the product, while fluorine NMR spectra for the species showed a singlet at $\delta \sim-119 \mathrm{ppm}$.

Subsequently, the reaction was repeated with 1 equiv. of adamantylamine (3) and 1 to generate the monosubstituted analog, 8. Three distinct resonances $(\delta-118.7,-129.7$, and -136.8 ) were identified in the ${ }^{19} \mathrm{~F}$ NMR, corresponding to the three inequivalent fluorines from the monosubstituted phthalonitrile. Further characterization by EI mass spectroscopy, FT-IR spectroscopy, and elemental analysis confirm the synthesis of the monosubstituted adamantylaminesubstituted analog.

Each of the above phthalonitriles (6-10) was condensed with 1-octanol and phenyl or 4-methoxyphenylmagnesium bromide to yield the corresponding magnesium phthalocyanine, as outlined in Scheme 2. The formed Pcs were all purified by flash silica gel column chromatography, eluting with a solvent mixture of hexane - ethyl acetate, and subsequently characterized by MALDI mass spectroscopy (MALDI-MS), elemental analyses, UV-vis spectrophotometry, and NMR analyses. The mass spectra of all magnesium phthalocyanines gave the expected parent ion clusters. In addition, daughter ion clusters corresponding to the loss of the adamantanyl fragments cleaved at the alkyl-heteroatom bond were also detected.

The ${ }^{1} \mathrm{H}$ NMR spectra for all magnesium phthalocyanines exhibited resonances for the adamantanyl protons between 1.6 and $2.3 \mathrm{ppm}$. In the $\mathrm{OCH}_{2}$ region for the hexadecaadamantylmethoxysubstituted analog 14, a broad singlet was observed. A similar nickel phthalocyanine bearing hexadecacyclohexylmethoxyl moieties revealed temperaturedependant separation of the peripherally and nonperipherally substituted methylene protons and that at room temperature the two chemically different proton pairs appeared as a broad singlet (19) The peripheral and nonperipheral $\mathrm{OCH}_{2}$ protons for the hexadecaadamantylethoxyphthalocyanine $\mathbf{1 5}$ are chemically inequivalent and appeared as distinct triplets at 4.27 and $4.16 \mathrm{ppm}$, respectively. As expected, the ${ }^{19} \mathrm{~F}$ NMR for the hexadecasubstituted analogs showed no fluorine resonances, while the octaadamantyloctafluoro Pcs 11 and 12 exhibited singlets at approximately $-120 \mathrm{ppm}$. However, the ${ }^{19} \mathrm{~F}$ NMR for the tetrasubstituted analog 13 , which consists of a mixture of isomers, revealed multiple fluorine resonances corresponding to the multitude of inequivalent fluorines formed during the phthalocyanine condensation reaction.

A comparison of the UV-vis spectra for the Mg Pcs exhibits the expected red shifts owing to the substitution onto the macrocyclic aromatic ring, as shown in Table 1. Each of the hexadecasubstituted compounds exhibited a pronounced red shift of the $Q$ band, with $\lambda_{\max }$ values similar to those reported in the literature for magnesium hexadecaneopentoxyphthalocyanine $(754 \mathrm{~nm})(6,7)$. The tetrasubstituted derivative 13 was not red-shifted as greatly as the octaadamantylamine derivative, further supporting the association between large, sterically bulky substituents and the red shift of the corresponding UV-vis spectra. As compared
Scheme 2.

\section{$6-10$}

1. 1-octanol +
ArMgX

2. 4 days at $120^{\circ} \mathrm{C}$

3. 11-16 AcOH

$\checkmark$

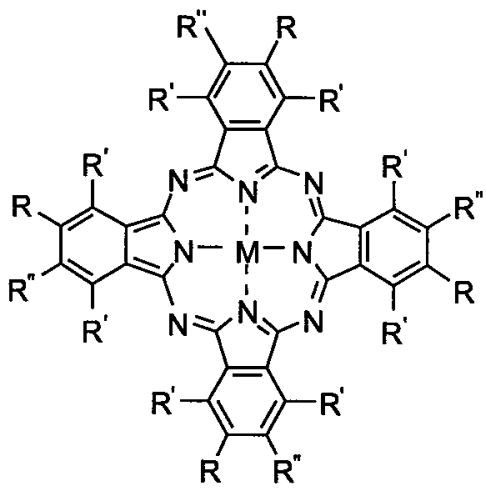

$11 \mathrm{R}=\mathrm{R}^{\prime \prime}=$ OAda, $\mathrm{R}^{\prime}=\mathrm{F}, \mathrm{M}=\mathrm{Mg}$

$12 \mathrm{R}=\mathrm{R}^{\prime \prime}=\mathrm{NHAda}, \mathrm{R}^{\prime}=\mathrm{F}, \mathrm{M}=\mathrm{Mg}$

$13 R=N H A d a, R^{\prime}=R^{\prime \prime}=F, M=M g$

$14 \mathrm{R}=\mathrm{R}^{\prime}=\mathrm{R}^{\prime \prime}=\mathrm{OCH}_{2} \mathrm{Ada}, \mathrm{M}=\mathrm{Mg}$

$15 \mathrm{R}=\mathrm{R}^{\prime}=\mathrm{R}^{\prime \prime}=\mathrm{OCH}_{2} \mathrm{CH}_{2} \mathrm{Ada}, \mathrm{M}=\mathrm{Mg}$

$16 \mathrm{R}=\mathrm{R}^{\prime \prime}=$ OAda, $\mathrm{R}^{\prime}=\mathrm{F}, \mathrm{M}=\mathrm{H}_{2}$

Table 1. Summary of the UV-vis spectra for the adamantane-substituted magnesium phthalocyanines.

\begin{tabular}{ll}
\hline $\mathrm{Mg} \mathrm{Pc}$ & $\boldsymbol{\lambda}_{\max }(\log \varepsilon)$ \\
\hline $\mathbf{1 1}$ & $708(4.83)$ \\
$\mathbf{1 2}$ & $794(4.57)$ \\
$\mathbf{1 3}$ & $714(4.63)$ \\
$\mathbf{1 4}$ & $752(4.91)$ \\
$\mathbf{1 5}$ & $744(4.93)$ \\
\hline
\end{tabular}

with the tetrasubstituted analog, the octaadamantylaminesubstituted derivative exhibited a red shift of $80 \mathrm{~nm}$. It is possible that these bulky adamantylamino groups, even at the peripheral positions, distort the planar Pc ring, causing this red shift. Not surprisingly, a small decrease in the $\lambda_{\max }$ was detected upon insertion of a methylene unit for the hexadecasubstituted analogs $\mathbf{1 5}$, as compared with $\mathbf{1 4}$, as the extra methylene group in $\mathbf{1 5}$ will position the bulky adamantyl group further from the core of the Pc.

Metal-free Pcs are useful intermediates for transmetallating synthetically challenging complexes. A metalfree phthalocyanine analog $\mathbf{1 6}$ was synthesized after refluxing the magnesium derivative $\mathbf{1 1}$ in acetic acid. Purification was achieved by flash silica gel column chromatogra- 
Fig. 1. MALDI-MS spectra for 19 showing parent ion cluster $[\mathrm{M}+\mathrm{H}]^{+}$at 3418 , along with daughter ion clusters separated by 163 amu $\left(\mathrm{C}_{12} \mathrm{H}_{19}\right)$.

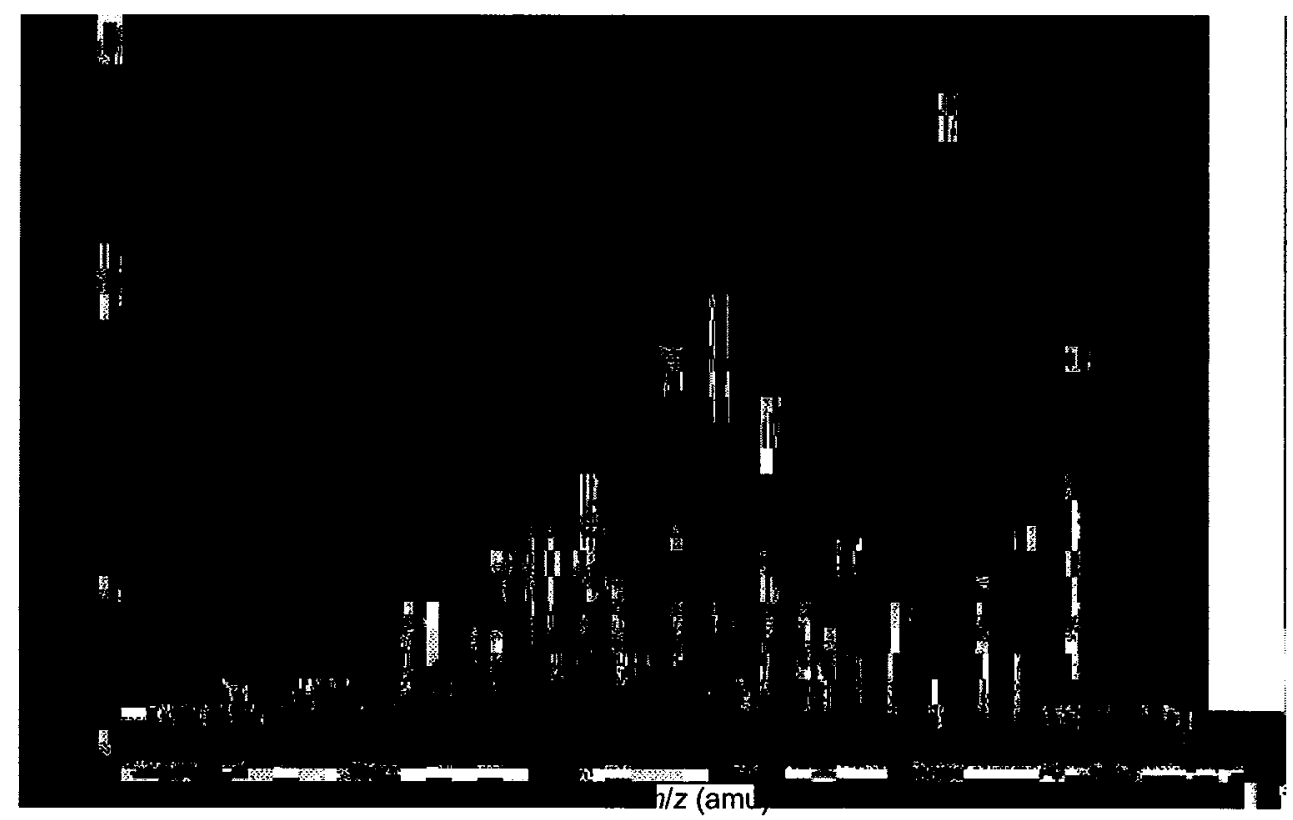

phy with hexane - ethyl acetate used as the mobile phase. This compound was characterized by MALDI-MS and again revealed the expected parent ion cluster at 1883 amu. A series of daughter ion clusters were observed separated by 135 amu, corresponding to the loss of an adamantanyl unit $\left(\mathrm{C}_{10} \mathrm{H}_{15}\right)$. The complex was further characterized by NMR spectroscopy, elemental analysis, and UV-vis spectrophotometry, with the $\lambda_{\max }$ of the $\mathrm{Q}$ band red-shifted by $26-$ $764 \mathrm{~nm}$ with respect to the magnesium derivative. Following the isolation and characterization of the metal-free derivative, repeated attempts to introduce manganese into the core of the phthalocyanine were unsuccessful.

Due to the difficulty associated with forming the metalfree phthalocyanines incorporating adamantane-based substituents, a multistep synthesis for transmetalating Pcs was not viable. Therefore, direct condensation of precursor phthalonitriles with nickel as the core metal ion was pursued. As previously described (19), the general synthetic approach is outlined in Scheme 3 in which 6, 9, or 10 was heated with $\mathrm{NiCl}_{2}$ in $N, N$-dimethylaminoethanol (DMAE) for 4 days at $120{ }^{\circ} \mathrm{C}$ to give the nickel phthalocyanines 1719, respectively. Again, MALDI-MS revealed the expected parent ion clusters, in addition to daughter ion clusters corresponding to fragmentation between the alkyl substituents and oxygen. For the octaadamantyloctafluoro-nickel Pc 17, the daughter ions were separated by $135 \mathrm{amu}$, while the daughter ion clusters for the hexadecaadamantylmethoxynickel Pc 18 were separated by $149 \mathrm{amu}$ and the daughter ion peaks corresponding to hexadecaadamantylethoxysubstituted analog were separated by $163 \mathrm{amu}$, as shown in Fig. 1. Similar to the magnesium $\mathrm{Pc}$ analogs, the $\mathrm{OCH}_{2}$ resonances for the adamantylmethoxyphthalocyanine 18 appeared as a broad signal at $4.21 \mathrm{ppm}$ representing both the peripheral and nonperipheral substituents, while two clearly distinct triplet resonances at 4.78 and $4.53 \mathrm{ppm}$ were ob-
Scheme 3.

$$
6,9,10
$$

1. $\mathrm{NiCl}_{2}$, DMAE

2. 4 days at $120^{\circ} \mathrm{C}$

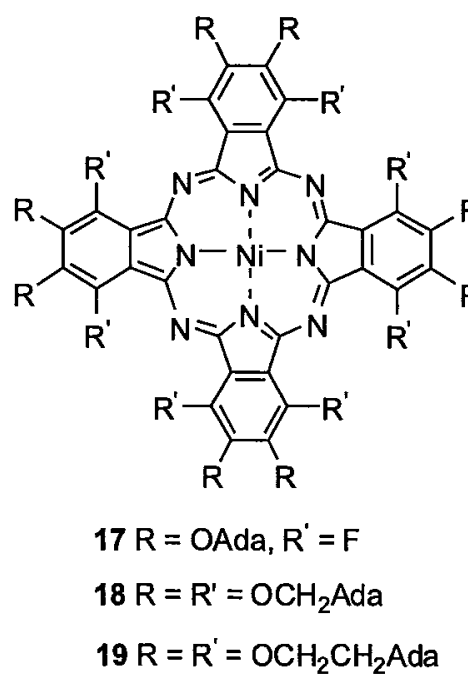

served for the peripheral and nonperipheral $\mathrm{OCH}_{2}$ protons, respectively, of the adamantylethoxyl Pc 19. UV-vis spectra were recorded for the three nickel phthalocyanines (summarized in Table 2), although the $\mathrm{Q}$ bands are not as red-shifted as the corresponding magnesium phthalocyanines. The most sterically congested nickel Pc (18) exhibited the greatest red 
Table 2. Summary of the UV-vis spectra for the adamantane-substituted nickel phthalocyanines.

\begin{tabular}{ll}
\hline Ni Pc & $\lambda_{\max }(\log \varepsilon)$ \\
\hline $\mathbf{1 7}$ & $708(4.91), 636(4.23)$ \\
$\mathbf{1 8}$ & $750(4.93), 672(4.43)$ \\
$\mathbf{1 9}$ & $736(4.88), 660(4.25)$ \\
\hline
\end{tabular}

shift, while the octaadamantyloxy-octafluorophthalocyanine 17 was the least red-shifted nickel complex. Perhaps some aggregation in 17-19 resulted in somewhat lower $\log \varepsilon$ values than usual. This reinforces the association between large sterically hindered substitutions onto the aromatic macrocycle and the red shifting of the $\mathrm{Q}$ band for phthalocyanines, although the $\lambda_{\max }$ for $\mathbf{1 8}$ was slightly less red-shifted as compared with hexadecaneopentoxyphthalocynaninato nickel $(750$ vs. $758 \mathrm{~nm})(19)$.

\section{Experimental}

\section{General methods}

Inert atmosphere conditions were maintained using Air Liquide prepurified argon. Magnetic stirring methods were utilized during all reactions. Flash chromatography was performed using silica gel of particle size $40-63 \mu \mathrm{m}$, with eluting solvents mixtures as described. Nuclear magnetic resonance (NMR) spectroscopy for proton and fluorine was performed using a Bruker 300 spectrometer at room temperature and was processed using XWIN-NMR 3.5 software. Chemical shifts are reported in parts per million $(\delta)$. Infrared (IR) spectra were recorded on a Mattson 3000 FT-IR spectrometer using $\mathrm{KBr}$ discs. UV-vis were recorded on a Hewlett-Packard HP8452A diode array spectrophotometer. For all phthalonitriles, low-resolution mass spectra (MS) were recorded in electron ionization $(70 \mathrm{eV})$ mode on a Micromass/Waters GCT time-of-flight instrument. For all phthalocyanines, low-resolution MS were recorded using laser desorption ionization (LDI) on a PE Sciex Q-STAR XL or PerSeptive Biosystems Voyager - DE STR spectrometer. Microanalyses were performed by Guelph Chemical Laboratory Ltd., Guelph, Ontario.

\section{Synthesis of 4,5-di-(1-adamantyloxy)-3,6-difluoro- phthalonitrile (6)}

1-Adamantanol (2, $1.50 \mathrm{~g}, 9.85 \mathrm{mmol}, 2$ equiv.) was dissolved in $10 \mathrm{~mL}$ of THF and the solution was stirred under an argon atmosphere at room temperature. To this solution was added $n$-butyllithium in hexanes $(4.94 \mathrm{~mL}, 2 \mathrm{~mol} / \mathrm{L}, 2$ equiv.). The reaction mixture initially turned cloudy and a fine white precipitate was observed. The mixture was stirred for $1 \mathrm{~h}$ before a solution of 3,4,5,6-tetrafluorophthalonitrile (1, $0.986 \mathrm{~g}, 4.93 \mathrm{mmol}, 1$ equiv.) in THF was added dropwise under argon. The reaction mixture turned reddishpurple and was stirred at room temperature for $4 \mathrm{~h}$. After this period, $100 \mathrm{~mL}$ of water was added to the reaction mixture and the mixture was extracted with diethyl ether $(3 x$ $50 \mathrm{~mL}$ ). After drying over sodium sulfate, the solvent was removed under reduced pressure, resulting in an ambercoloured oil. The oil was then dissolved in a minimum of toluene and was passed through a flash silica gel column using toluene as eluant. The first fraction was collected and the solvent was removed under reduced pressure, yielding an oil that solidified upon sitting under a stream of air overnight. Yield: $76 \%(1.74 \mathrm{~g}) ; \mathrm{mp} 196-198{ }^{\circ} \mathrm{C}$. TLC (toluene): $R_{f}$ 0.63. IR (KBr, $\left.\mathrm{cm}^{-1}\right)$ v: 2911, 2846, $2239(\mathrm{CN}), 1454,1354$, $1295,1113,1042 .{ }^{1} \mathrm{H}$ NMR $\left(\mathrm{CDCl}_{3}\right) \delta: 2.24$ (br m, 6H, bridgehead $\mathrm{C}-\mathrm{H}), 1.93\left(\mathrm{~m}, 12 \mathrm{H}, \mathrm{CH}_{2}\right), 1.68(\mathrm{br} \mathrm{m}, 12 \mathrm{H}$, $\mathrm{CH}_{2}$ ). ${ }^{19} \mathrm{~F} \mathrm{NMR}\left(\mathrm{CDCl}_{3}\right) \delta:-114.9$ (s). EI-MS $\mathrm{m} / z$ (rel. intensity): $\mathrm{M}^{+} 464$ (64). Anal. calcd. for $\mathrm{C}_{28} \mathrm{H}_{30} \mathrm{O}_{2} \mathrm{~N}_{2} \mathrm{~F}_{2}: \mathrm{C}$ 72.39, H 6.51, N 6.03; found: C 72.42, H 6.34, N, 6.11.

\section{Synthesis of 4,5-di-(1-adamantylamino)-3,6- difluorophthalonitrile (7)}

1-Adamantylamine $(3,1.52 \mathrm{~g}, 10.1 \mathrm{mmol}, 2$ equiv.) was dissolved in $15 \mathrm{~mL}$ of THF and the solution was stirred under an argon atmosphere at room temperature. To this was added $n$-butyllithium in hexanes $(4.0 \mathrm{~mL}, 2.5 \mathrm{~mol} / \mathrm{L}$, 2 equiv.). The reaction mixture initially turned cloudy and a fine white precipitate was observed. The mixture was stirred for $1 \mathrm{~h}$ before a solution of 3,4,5,6-tetrafluorophthalonitrile (1, $0.986 \mathrm{~g}, 4.93 \mathrm{mmol}, 1$ equiv.) in THF was added dropwise under argon. The reaction mixture turned dark red and was stirred at room temperature for $4 \mathrm{~h}$. After this period, $100 \mathrm{~mL}$ of water was added to the reaction mixture and was extracted with diethyl ether $(3 \times 50 \mathrm{~mL})$. After drying over sodium sulfate, the solvent was removed under reduced pressure, resulting in an amber-coloured oil. The oil was then dissolved in a minimum of toluene and was passed through a flash silica gel column using toluene for elution. The first fraction was collected and the solvent was removed under reduced pressure, yielding an oil that solidified upon sitting under a stream of air overnight. Yield: $52 \%(1.12 \mathrm{~g})$; mp $184-186{ }^{\circ} \mathrm{C}$. TLC (toluene): $R_{f} 0.61$. IR $\left(\mathrm{KBr}, \mathrm{cm}^{-1}\right) \mathrm{v}$ : $3377,2910,2850,2225(\mathrm{CN}), 1594,1515,1453,1384$, 1359, 1306. ${ }^{1} \mathrm{H}$ NMR $\left(\mathrm{CDCl}_{3}\right) \delta: 4.05$ (br s, $\left.2 \mathrm{H}, \mathrm{N}-\mathrm{H}\right), 2.20$ (br s, 6H, bridgehead $\mathrm{C}-\mathrm{H}), 1.94\left(\mathrm{~m}, 6 \mathrm{H}, \mathrm{CH}_{2}\right), 1.85(\mathrm{~m}, 6 \mathrm{H}$, $\left.\mathrm{CH}_{2}\right), 1.70\left(\mathrm{~m}, 12 \mathrm{H}, \mathrm{CH}_{2}\right) .{ }^{19} \mathrm{~F}$ NMR $\left(\mathrm{CDCl}_{3}\right) \delta:-119.6$. EIMS $m / z$ (rel. intensity): $\mathrm{M}^{+} 462$ (100). Anal. calcd. for $\mathrm{C}_{28} \mathrm{H}_{32} \mathrm{~N}_{4} \mathrm{~F}_{2}$ : C 72.70, $\mathrm{H} \mathrm{6.97,} \mathrm{N} \mathrm{12.11;} \mathrm{found:} \mathrm{C} \mathrm{72.89,} \mathrm{H}$ $7.20, \mathrm{~N} 12.16$.

\section{Synthesis of 4-(1-adamantylamino)-3,5,6- trifluorophthalonitrile (8)}

1-Adamantylamine (3,0.76 g, $5.0 \mathrm{mmol}, 1$ equiv.) was dissolved in $15 \mathrm{~mL}$ of THF and the solution was stirred under an argon atmosphere at room temperature. To this solution was added $n$-butyllithium in hexanes $(2.0 \mathrm{~mL}$, $2.5 \mathrm{~mol} / \mathrm{L}, 1$ equiv.). The reaction mixture initially turned cloudy and a fine white precipitate was observed. The reaction was stirred for $1 \mathrm{~h}$ before a solution of 3,4,5,6tetrafluorophthalonitrile $(1,0.986 \mathrm{~g}, 4.93 \mathrm{mmol}, \mathrm{I}$ equiv.) in THF was added dropwise under argon. It was then stirred at room temperature for $4 \mathrm{~h}$ and worked up as for 7 . IR $\left(\mathrm{KBr}, \mathrm{cm}^{-1}\right)$ v: $3418,3382,2912,2854,2231(\mathrm{CN}), 1566$, 1452, 1382, 1108. Yield: $58 \%(0.95 \mathrm{~g})$; $\mathrm{mp} 135-137{ }^{\circ} \mathrm{C}$. TLC (toluene): $R_{f} 0.65 .{ }^{1} \mathrm{H}$ NMR $\left(\mathrm{CDCl}_{3}\right) \delta: 3.42(\mathrm{br} \mathrm{s}, 1 \mathrm{H}$, $\mathrm{N}-\mathrm{H}), 2.19$ (br s, 3H, bridgehead C-H), 1.93 (br s, 6H, $\mathrm{CH}_{2}$ ), 1.71 (br s, $\left.6 \mathrm{H}, \mathrm{CH}_{2}\right) .{ }^{19} \mathrm{~F}$ NMR $\left(\mathrm{CDCl}_{3}\right) \delta:-118.7(\mathrm{~m}),-$ $129.7(\mathrm{~m}),-136.8(\mathrm{~m})$. EI-MS $\mathrm{m} / \mathrm{z}$ (rel. intensity): $\mathrm{M}^{+} 331$ (47). Anal. calcd. for $\mathrm{C}_{18} \mathrm{H}_{16} \mathrm{~N}_{3} \mathrm{~F}_{3}$ : C 65.25, H 4.87, N 12.68; found: C $65.03, \mathrm{H} 4.85, \mathrm{~N} 12.78$. 
Synthesis of 3,4,5,6-tetra-(1-adamantylmethoxy)phthalonitrile (9)

1-Adamantanemethanol $(4,5.0 \mathrm{~g}, 30.1 \mathrm{mmol}, 24$ equiv. $)$, potassium carbonate $(5 \mathrm{~g}, 36 \mathrm{mmol}, 30$ equiv. $)$, and 3,4,5,6tetrafluorophthalonitrile $(1,1.0 \mathrm{~g}, 5 \mathrm{mmol}, 1$ eq.) were dissolved in $12 \mathrm{~mL}$ DMF and the reaction mixture was heated to $120^{\circ} \mathrm{C}$ for 4 days. After this period, $100 \mathrm{~mL}$ of water was added to the reaction mixture, which was subsequently extracted with diethyl ether $(3 \times 75 \mathrm{~mL})$. After drying over sodium sulfate, the solvent was removed under reduced pressure, yielding an amber-coloured oil. The oil was dissolved in a minimum of dichloromethane and was passed through a flash silica gel column using dichloromethanemethanol $(20: 1)$ as eluant. The first fraction was collected and the solvent was removed under reduced pressure, yielding an amber oil that solidified to an off-white solid under a stream of air overnight. Yield: $78 \%(3.07 \mathrm{~g}) ; \mathrm{mp} 173-$ $176{ }^{\circ} \mathrm{C}$. TLC (toluene): $R_{f} 0.66$. IR $\left(\mathrm{KBr}, \mathrm{cm}^{-1}\right)$ v: 2943 , 2917, 2230 (CN), 1558, 1489, 1358, 1101. ${ }^{1} \mathrm{H}$ NMR $\left(\mathrm{CDCl}_{3}\right)$ 8: $3.69\left(\mathrm{~s}, 4 \mathrm{H}, \mathrm{CH}_{2}\right), 3.68\left(\mathrm{~s}, 4 \mathrm{H}, \mathrm{CH}_{2}\right), 2.04(\mathrm{~m}$, $12 \mathrm{H}$, bridgehead $\mathrm{C}-\mathrm{H}), 1.71\left(\mathrm{~m}, 24 \mathrm{H}, \mathrm{CH}_{2}\right), 1.67(\mathrm{~m}, 24 \mathrm{H}$, $\mathrm{CH}_{2}$ ). EI-MS $\mathrm{m} / \mathrm{z}$ (rel. intensity): $\mathrm{M}^{+} 784$ (41). Anal. calcd. for $\mathrm{C}_{52} \mathrm{H}_{68} \mathrm{O}_{4} \mathrm{~N}_{2}: \mathrm{C} 79.55, \mathrm{H} 8.73, \mathrm{~N} 3.57$; found: C 79.14, $\mathrm{H}$ 9.07, N 3.59.

\section{Synthesis of 3,4,5,6-tetra-(1-adamantylethoxy)phthalo- nitrile (10)}

1-Adamantaneethanol $(5,5.0 \mathrm{~g}, 27.8 \mathrm{mmol}, 8$ equiv.), potassium carbonate $(4.3 \mathrm{~g}, 32 \mathrm{mmol}, 8$ equiv.), and $3,4,5,6-$ tetrafluorophthalonitrile $(1,0.7 \mathrm{~g}, 3.5 \mathrm{mmol}, 1$ equiv.) were added to $12 \mathrm{~mL}$ of DMF and the reaction mixture was heated to $120^{\circ} \mathrm{C}$ for 4 days. The work-up proceeded as for 9, but dichloromethane-methanol (10:1) was used as eluant. Yield: $81 \%(2.39 \mathrm{~g}) ; \mathrm{mp} 166-168{ }^{\circ} \mathrm{C}$. TLC (toluene): $R_{f}$ 0.68. IR $\left(\mathrm{KBr}, \mathrm{cm}^{-1}\right)$ v: $2935,2846,2231(\mathrm{CN}), 1559,1448$, $1382,1371,1244,1106 .{ }^{1} \mathrm{H}$ NMR $\left(\mathrm{CDCl}_{3}\right) \delta: 4.19(\mathrm{~m}, 8 \mathrm{H}$, $\left.\mathrm{OCH}_{2}\right), 1.98(\mathrm{br} \mathrm{s}, 12 \mathrm{H}$, bridgehead $\mathrm{C}-\mathrm{H}), 1.67(\mathrm{~m}, 24 \mathrm{H}$, $\left.\mathrm{CH}_{2}\right), 1.56\left(\mathrm{~m}, 32 \mathrm{H}, \mathrm{OCH}_{2} \mathrm{CH}_{2}\right.$ and adamantyl $\left.\mathrm{CH}_{2}\right)$. EI-MS $\mathrm{m} / \mathrm{z}$ (rel. intensity): $\mathrm{M}^{+} 840(51)$. Anal. calcd. for $\mathrm{C}_{56} \mathrm{H}_{76} \mathrm{O}_{4} \mathrm{~N}_{2}$ : C 79.96, H 9.11, N 3.33; found: C 79.60, H 9.35, N 3.32.

Synthesis of magnesium $2,3,9,10,16,17,23,24-o c t a-(1-$ adamantyloxy)-1,4,8,11,15,18,22,25-octafluorophthalocyanine (11)

4-Methoxyphenylmagnesium bromide $(2 \mathrm{~mL}, 0.5 \mathrm{~mol} / \mathrm{L}$ in THF) was added to $3 \mathrm{~mL}$ of 1-octanol and the mixture was stirred for $0.5 \mathrm{~h}$ under argon at room temperature. To this was added 4,5-di-(1-adamantyloxy)-3,6-difluorophthalonitrile (6) $(0.250 \mathrm{~g}, 0.53 \mathrm{mmol})$ and the mixture was heated under argon to $120^{\circ} \mathrm{C}$. Upon heating, the clear, colourless mixture turned green. After heating for $24 \mathrm{~h}, 50 \mathrm{~mL}$ of methanol was added and a green solid precipitated out of solution. The solid was collected by centrifugation and was washed with water and methanol. The crude product was then passed through a flash silica gel column eluting with hexane - ethyl acetate (9:1). The first fraction was collected and the solvent was removed under reduced pressure, yielding a dark green solid. Yield: $34 \%(0.085 \mathrm{~g}) ; \mathrm{mp}>300^{\circ} \mathrm{C}$. TLC (hexane - ethyl acetate, 5:1): $\boldsymbol{R}_{f} \mathbf{0 . 7 2}$. UV-vis (dichloromethane) $\lambda_{\max }(\log \varepsilon)(\mathrm{nm}): 708$ (4.83), 636 (4.06), 364 (4.43), 318 (4.37). ${ }^{1} \mathrm{H}$ NMR $\left(\mathrm{CDCl}_{3}\right) \delta: 2.50$ (br s, $24 \mathrm{H}$, bridgehead $\mathrm{C}-\mathrm{H}), 2.31\left(\mathrm{~m}, 48 \mathrm{H}, \mathrm{CH}_{2}\right), 2.22\left(\mathrm{~m}, 48 \mathrm{H}, \mathrm{CH}_{2}\right)$. ${ }^{19} \mathrm{~F}$ NMR $\left(\mathrm{CDCl}_{3}\right) \delta$ : -119.2 . MALDI-MS $\mathrm{m} / \mathrm{z}$ (rel. intensity): $1883[\mathrm{M}]^{+}(10), 1748\left[\mathrm{M}-\mathrm{C}_{10} \mathrm{H}_{15}\right]^{+}(21), 1613[\mathrm{M}-$ $\left.2\left(\mathrm{C}_{10} \mathrm{H}_{15}\right)\right]^{+}(25), 1478\left[\mathrm{M}-3\left(\mathrm{C}_{10} \mathrm{H}_{15}\right)\right]^{+}$. Anal. calcd. for $\mathrm{C}_{112} \mathrm{H}_{120} \mathrm{O}_{8} \mathrm{~N}_{8} \mathrm{~F}_{8} \mathrm{Mg}$ : C 71.46, $\mathrm{H}$ 6.43, N 5.95; found: $\mathrm{C}$ $71.48, \mathrm{H} 6.44, \mathrm{~N}, 6.11$

\section{Synthesis of magnesium 2,3,9,10,16,17,23,24-octa-(1- adamantylamino)-1,4,8,11,15,18,22,25-octafluoro- phthalocyanine (12)}

4-Methoxyphenylmagnesium bromide $(2 \mathrm{~mL}, 0.5 \mathrm{~mol} / \mathrm{L}$ in THF) was added to $3 \mathrm{~mL}$ of 1-octanol and the mixture was stirred for $0.5 \mathrm{~h}$ under argon at room temperature. To this was added 4,5-di-(1-adamantylamino)-3,6-difluorophthalonitrile $(7,0.250 \mathrm{~g}, 0.53 \mathrm{mmol})$ and the mixture was heated under argon to $120{ }^{\circ} \mathrm{C}$. Upon heating, the clear, colourless mixture turned red and was worked up as for 11, yielding a dark green solid. Yield: $17 \%(0.042 \mathrm{~g})$; $\mathrm{mp}$ $>300{ }^{\circ} \mathrm{C}$. TLC (hexane - ethyl acetate, 5:1): $R_{f} 0.72$. UV-vis (dichloromethane) $\lambda_{\max }(\log \varepsilon)(\mathrm{nm}): 794(4.57), 708(4.09)$, 478 (4.04), 358 (4.34), 322 (4.34). ${ }^{1} \mathrm{H}$ NMR $\left(\mathrm{CDCl}_{3}\right) \delta: 2.11$ $(\mathrm{m}, 24 \mathrm{H}$, bridgehead $\mathrm{C}-\mathrm{H}), 1.87\left(\mathrm{~m}, 48 \mathrm{H}, \mathrm{CH}_{2}\right), 1.68(\mathrm{~m}$, $48 \mathrm{H}, \mathrm{CH}_{2}$ ). MALDI-MS $m / z$ (rel. intensity): $1872[\mathrm{M}]^{+} 100$. Anal. calcd. for $\mathrm{C}_{112} \mathrm{H}_{128} \mathrm{~N}_{16} \mathrm{~F}_{8} \mathrm{Mg}$ : C 71.76, H 6.88, N 11.95; found: C 71.87, H 7.27, N 11.24.

\section{Synthesis of magnesium 2,9,16,23-tetra-(1- adamantylamino)-1,3,4,8,10,11,15,17,18,22,24,25- dodecafluorophthalocyanine (13)}

4-Methoxyphenylmagnesium bromide $(2 \mathrm{~mL}, 0.5 \mathrm{~mol} / \mathrm{L}$ in THF) was added to $3 \mathrm{~mL}$ of 1 -octanol and the mixture was stirred for $0.5 \mathrm{~h}$ under argon at room temperature. To this was added 4-(1-adamantylamino)-3,5,6-trifluorophthalonitrile $(8,0.250 \mathrm{~g}, 0.75 \mathrm{mmol})$ and the mixture was heated under argon to $120{ }^{\circ} \mathrm{C}$. Upon heating, the clear, colourless mixture turned green. After heating for $24 \mathrm{~h}, 50 \mathrm{~mL}$ of methanol was added and a green solid precipitated out of solution and was worked up as for 11, yielding a dark green solid. Yield: $21 \%(0.053 \mathrm{~g}) ; \mathrm{mp}>300{ }^{\circ} \mathrm{C}$. TLC (hexane ethyl acetate, 9:1): $R_{f} 0.62$. UV-vis (dichloromethane) $\lambda_{\max }$ $(\log \varepsilon)(\mathrm{nm}): 714$ (4.63), 646 (4.07), 362 (4.37). ${ }^{1} \mathrm{H}$ NMR $\left(\mathrm{CDCl}_{3}\right) \delta: 3.82(\mathrm{br} \mathrm{s}, 4 \mathrm{H}, \mathrm{NH}), 2.18(\mathrm{~m}, 12 \mathrm{H}$, bridgehead C$\mathrm{H}), 1.71-1.96\left(\mathrm{~m}, 24 \mathrm{H}, \mathrm{CH}_{2}\right), 1.58\left(\mathrm{br} \mathrm{s}, 24 \mathrm{H}, \mathrm{CH}_{2}\right)$. ${ }^{19} \mathrm{~F} \mathrm{NMR}\left(\mathrm{CDCl}_{3}\right) \delta:-128(\mathrm{~m}),-138(\mathrm{~m})$. MALDI-MS $\mathrm{m} / \mathrm{z}$ (rel. intensity): $1348[\mathrm{M}]^{+}(100), 1213\left[\mathrm{M}-\mathrm{C}_{10} \mathrm{H}_{15}\right]^{+}(63)$, $1078\left[\mathrm{M}-2\left(\mathrm{C}_{10} \mathrm{H}_{15}\right)\right]^{+}(53), 943\left[\mathrm{M}-4\left(\mathrm{C}_{10} \mathrm{H}_{15}\right)\right]^{+}(24)$. Anal. calcd. for $\mathrm{C}_{72} \mathrm{H}_{64} \mathrm{~N}_{12} \mathrm{~F}_{12} \mathrm{Mg}$ : C 64.07, $\mathrm{H} 4.78, \mathrm{~N}$ 12.45; found: C 64.44, $\mathrm{H} 4.94, \mathrm{~N} 12.78$

\section{Synthesis of magnesium $1,2,3,4,8,9,10,11,15,16,17,18$, $22,23,24,25$-hexadeca-(1-adamantylmethoxy)phthalo- cyanine (14)}

4-Methoxyphenylmagnesium bromide was added $(2 \mathrm{~mL}$, $0.5 \mathrm{~mol} / \mathrm{L}$ in THF) to $3 \mathrm{~mL}$ of 1 -octanol and the mixture was stirred for $0.5 \mathrm{~h}$ under argon at room temperature. To this was added 3,4,5,6-tetraadamantylmethoxyphthalonitrile (9, $0.250 \mathrm{~g}, 0.32 \mathrm{mmol}$ ) and the mixture was heated under argon to $120^{\circ} \mathrm{C}$. Upon heating, the clear, colourless mixture turned green. After heating for $24 \mathrm{~h}, 50 \mathrm{~mL}$ of methanol was added and a green solid precipitated out of solution and was worked up as for 11, yielding a dark green solid. Yield: $15 \%$ 
$(0.039 \mathrm{~g}) ; \mathrm{mp}>300{ }^{\circ} \mathrm{C}$. TLC (hexane - ethyl acetate, 15:1): $R_{f}$ 0.52. UV-vis (dichloromethane) $\lambda_{\max }(\log \varepsilon)(\mathrm{nm}): 752$ (4.91), 672 (4.12), 364 (4.19). ${ }^{1} \mathrm{H}$ NMR $\left(\mathrm{CDCl}_{3}\right)$ 8: 3.49 (br s, 32H, $\left.\mathrm{OCH}_{2}\right), 2.00(\mathrm{~m}, 48 \mathrm{H}$, bridgehead $\mathrm{C}-\mathrm{H}), 1.70$ $1.90\left(\mathrm{~m}, 192 \mathrm{H}, \mathrm{CH}_{2}\right.$ ). MALDI-MS $\mathrm{m} / \mathrm{z}$ (rel. intensity): 3160 $\left[\mathrm{M}^{+}(49), \quad 3011\left[\mathrm{M}-\mathrm{C}_{11} \mathrm{H}_{17}\right]^{+}(57), 2862[\mathrm{M}\right.$ $2(\mathrm{C} 11 \mathrm{H} 17)]^{+}(100), 2713\left[\mathrm{M}-3\left(\mathrm{C}_{11} \mathrm{H}_{17}\right)\right]^{+}$(96). Anal. calcd. for $\mathrm{C}_{208} \mathrm{H}_{272} \mathrm{O}_{16} \mathrm{~N}_{8} \mathrm{Mg}$ : $\mathrm{C}$ 78.94, $\mathrm{H}$ 8.66, $\mathrm{N}$ 3.54; found: C $78.50, \mathrm{H} 8.47, \mathrm{~N}, 3.28$.

\section{Synthesis of magnesium 1,2,3,4,8,9,10,11,15,16,17,18, 22,23,24,25-hexadeca-(1-adamantaneethoxy)phthalo- cyanine (15)}

4-Methoxyphenylmagnesium bromide $(2 \mathrm{~mL}, 0.5 \mathrm{~mol} / \mathrm{L}$ in THF) was added to $3 \mathrm{~mL}$ of 1 -octanol and the mixture was stirred for $0.5 \mathrm{~h}$ under argon at room temperature. To this was added 3,4,5,6-tetra-(1-adamantylethoxy)phthalonitrile $(10,0.250 \mathrm{~g}, 0.30 \mathrm{mmol})$ and the mixture was heated under argon to $120^{\circ} \mathrm{C}$. Upon heating, the clear, colourless mixture turned green. After heating for $24 \mathrm{~h}, 50 \mathrm{~mL}$ of methanol was added and a green solid precipitated out of solution. The solid was collected by centrifugation and was washed with water and methanol. The crude product was then passed through a flash silica gel column eluting with hexane - ethyl acetate (9:1). The first fraction was collected and the solvent was removed under reduced pressure, yielding a dark green solid. Yield: $20 \%(0.051 \mathrm{~g}) ; \mathrm{mp}>300^{\circ} \mathrm{C}$. TLC (hexane - ethyl acetate, 15:1): $R_{f} 0.49$. UV-vis (dichloromethane) $\lambda_{\max }(\log \varepsilon)(\mathrm{nm}): 744$ (4.93), 668 (4.09), 328 (4.10). ${ }^{1} \mathrm{H} \mathrm{NMR}\left(\mathrm{CDCl}_{3}\right) \delta: 4.27(\mathrm{t}, 16 \mathrm{H}, J=9.0 \mathrm{~Hz}$, $\left.\mathrm{OCH}_{2}\right), 4.16\left(\mathrm{t}, 16 \mathrm{H}, J=9.0 \mathrm{~Hz}, \mathrm{OCH}_{2}\right), 1.99(\mathrm{br} \mathrm{s}, 48 \mathrm{H}$, bridgehead $\mathrm{C}-\mathrm{H}), 1.76\left(\mathrm{~m}, 96 \mathrm{H}, \mathrm{CH}_{2}\right), 1.61(\mathrm{~m}, 128 \mathrm{H}$, $\mathrm{OCH}_{2} \mathrm{OCH}_{2-}$ and $\mathrm{CH}_{2}$ ). MALDI-MS $\mathrm{m} / \mathrm{z}$ (rel. intensity): $3384[\mathrm{M}]^{+}(68), 3221\left[\mathrm{M}-\mathrm{C}_{12} \mathrm{H}_{19}\right]^{+}(71), 3058[\mathrm{M}-$ $\left.2\left(\mathrm{C}_{12} \mathrm{H}_{19}\right)\right]^{+}(95), 2895\left[\mathrm{M}-3\left(\mathrm{C}_{12} \mathrm{H}_{19}\right)\right]^{+}(89), 2732[\mathrm{M}-$ $\left.4\left(\mathrm{C}_{12} \mathrm{H}_{19}\right)\right]^{+}(83), 2569\left[\mathrm{M}-5\left(\mathrm{C}_{12} \mathrm{H}_{19}\right)\right]^{+}$(83), $2406[\mathrm{M}-$ $\left.6\left(\mathrm{C}_{12} \mathrm{H}_{19}\right)\right]^{+}$(100). Anal. calcd. for $\mathrm{C}_{224} \mathrm{H}_{304} \mathrm{O}_{16} \mathrm{~N}_{8} \mathrm{Mg}$ : $\mathrm{C}$ 79.38, H 9.04, N 3.31; found: C 78.77, H 9.41, N 3.78

\section{Synthesis of metal-free $2,3,9,10,16,17,23,24$-octa-(1- adamantyloxy)-1,4,8,11,15,18,22,25-octafluorophthalo- cyanine (16)}

Magnesium 2,3,9,10,16,17,23,24-octa-(1-adamantyloxy)$1,4,8,11,15,18,22,25$-octafluorophthalocyanine $(11,0.502 \mathrm{~g}$, $0.27 \mathrm{mmol}$ ) was dissolved in glacial acetic acid $(5 \mathrm{~mL})$ and the mixture was refluxed under air. After 4 days, the crude product was precipitated out of solution following the addition of absolute ethanol $(50 \mathrm{~mL})$. The dark green precipitate was washed with ethanol $(2 \times 30 \mathrm{~mL})$ and methanol $(1 \times$ $30 \mathrm{~mL}$ ). The crude product was purified by flash silica gel column chromatography using hexane - ethyl acetate $(4: 1)$ as eluant. The first fraction was collected and the solvent was removed under reduced pressure. Yield: $11 \%(55 \mathrm{mg})$; $\mathrm{mp}>300{ }^{\circ} \mathrm{C}$. TLC (hexane - ethyl acetate, $4: 1$ ): $R_{f} 0.80$. UV-vis (dichloromethane) $\lambda_{\max }(\log \varepsilon)(\mathrm{nm}): 734$ (4.02), 704 (4.01), 670 (3.51), $636(3.40), 358$ (3.63). ${ }^{1} \mathrm{H}$ NMR $\left(\mathrm{CDCl}_{3}\right)$ 8: $2.25(\mathrm{~m}, 24 \mathrm{H}$, bridgehead $\mathrm{C}-\mathrm{H}), 1.52-1.98(\mathrm{~m}$, $\left.96 \mathrm{H}, \mathrm{CH}_{2}\right) .{ }^{19} \mathrm{~F}\left(\mathrm{CDCl}_{3}\right) \delta:-119.2 . \mathrm{IR}\left(\mathrm{KBr}, \mathrm{cm}^{-1}\right)$ v: 3275 , 2915, 2853, 1732, 1653, 1456, 1300, 1281, 1048, 967. MALDI-MS $m / z$ (rel. intensity): $1858\left[\mathrm{M}^{+}(28), 1723[\mathrm{M}-\right.$ $\left.\mathrm{C}_{10} \mathrm{H}_{15}\right]^{+}(51), 1588\left[\mathrm{M}-2\left(\mathrm{C}_{10} \mathrm{H}_{15}\right)\right]^{+}(87), 1453[\mathrm{M}-$
$\left.3\left(\mathrm{C}_{10} \mathrm{H}_{15}\right)\right]^{+}$(100). Anal. calcd. for $\mathrm{C}_{112} \mathrm{H}_{122} \mathrm{O}_{8} \mathrm{~N}_{8} \mathrm{~F}_{8}: \quad \mathrm{C}$ 72.31, H 6.61, N 6.02; found: C 71.90, H 6.75, N 5.96.

Synthesis of nickel $2,3,9,10,16,17,23,24-o c t a-(1-$ adamantyloxy)-1,4,8,11,15,18,22,25-octafluorophthalocyanine (17)

4,5-Di-(1-adamantyloxy)-3,6-difluorophthalonitrile (6, $0.306 \mathrm{~g}, 0.65 \mathrm{mmol}$ ) and nickel(II) chloride $(90 \mathrm{mg}$, $0.7 \mathrm{mmol}$ ) were added to $4 \mathrm{~mL}$ of $N, N$-dimethylaminoethanol (DMEA). The mixture was heated to $145^{\circ} \mathrm{C}$ and stirred under argon. After stirring for $24 \mathrm{~h}$, a green solid was precipitated following the addition of $40 \mathrm{~mL}$ of water. The precipitate was collected by centrifugation. The crude product was purified by flash silica gel column chromatography with hexane - ethyl acetate (4:1) as eluant. The first fraction was collected and the solvent was removed under reduced pressure. Yield: $24 \%(0.076 \mathrm{~g}) ; \mathrm{mp}>300^{\circ} \mathrm{C}$. TLC (hexane ethyl acetate, 2:1): $R_{f} 0.81$. UV-vis (dichloromethane) $\lambda_{\max }$ $(\log \varepsilon)(\mathrm{nm}): 708$ (4.91), 636 (4.23), 342 (4.34), 304 (4.47). ${ }^{1} \mathrm{H} \mathrm{NMR}\left(\mathrm{CDCl}_{3}\right) \delta: 2.41$ (br s, $24 \mathrm{H}$, bridgehead $\left.\mathrm{C}-\mathrm{H}\right), 2.36$ (br m, 48H, $\left.\mathrm{CH}_{2}\right), 1.74\left(\mathrm{~m}, 48 \mathrm{H}, \mathrm{CH}_{2}\right) .{ }^{19} \mathrm{~F}$ NMR $\left(\mathrm{CDCl}_{3}\right) \delta$ : -126.1 . MALDI-MS $m / z$ (rel. intensity): $1914[\mathrm{M}]^{+}(10)$, $1779\left[\mathrm{M}-\mathrm{C}_{10} \mathrm{H}_{15}\right]^{+}(23), 1644\left[\mathrm{M}-2\left(\mathrm{C}_{10} \mathrm{H}_{15}\right)\right]^{+}(42), 1509$ $\left[\mathrm{M}-2\left(\mathrm{C}_{10} \mathrm{H}_{15}\right)\right]^{+}(67), 1374\left[\mathrm{M}-4\left(\mathrm{C}_{10} \mathrm{H}_{15}\right)\right]^{+}$(91). Anal. calcd. for $\mathrm{C}_{112} \mathrm{H}_{120} \mathrm{O}_{8} \mathrm{~N}_{8} \mathrm{~F}_{8} \mathrm{Ni}$ : C 70.18, $\mathrm{H}$ 6.31, N 5.85; found: C 69.91, H 6.78, N 5.74.

\section{Synthesis of nickel $1,2,3,4,8,9,10,11,15,16,17,18$,} 22,23,24,25-hexadeca-(1-adamantylmethoxy)phthalocyanine (18)

3,4,5,6-Tetra-(1-adamantylmethoxy)phthalonitrile $0.202 \mathrm{~g}, 0.26 \mathrm{mmol}$ ) and nickel(II) chloride $(36 \mathrm{mg}$, $0.28 \mathrm{mmol}$ ) were added to $4 \mathrm{~mL}$ of DMEA. The mixture was heated to $145^{\circ} \mathrm{C}$ and allowed to stir under argon. After stirring for $24 \mathrm{~h}$, a green solid was precipitated following the addition of $40 \mathrm{~mL}$ of water and was worked up as for 17 . Yield: $14 \%(29 \mathrm{mg}) ; \mathrm{mp}>300^{\circ} \mathrm{C}$. TLC (hexane - ethyl acetate, 9:1): $R_{f} 0.71$. UV-vis (dichloromethane) $\lambda_{\max }(\log \varepsilon$ ) (nm): 750 (4.93), 672 (4.43), 386 (4.55), 314 (4.77). ${ }^{1} \mathrm{H} \mathrm{NMR}\left(\mathrm{CDCl}_{3}\right) \delta$ : 4.21 (br m, 32H, $\left.\mathrm{OCH}_{2}\right), 2.10$ (br m, $24 \mathrm{H}$, bridgehead $\mathrm{CH}$ ), 1.98 (br $\mathrm{m}, 24 \mathrm{H}$, bridgehead $\mathrm{CH}$ ), 1.61-1.88 (m, 192H, $\mathrm{CH}_{2}$ ). MALDI-MS $\mathrm{m} / \mathrm{z}$ (rel. intensity): $3214\left[\mathrm{M}+\mathrm{H}_{2} \mathrm{O}\right]^{+}(38), 3065\left[\mathrm{M}+\mathrm{H}_{2} \mathrm{O}-\mathrm{C}_{11} \mathrm{H}_{17}\right]^{+}$(52), $2916\left[\mathrm{M}+\mathrm{H}_{2} \mathrm{O}-2\left(\mathrm{C}_{11} \mathrm{H}_{17}\right)\right]^{+}(53), 2769\left[\mathrm{M}+\mathrm{H}_{2} \mathrm{O}-\right.$ $\left.3\left(\mathrm{C}_{11} \mathrm{H}_{17}\right)\right]^{+}$(94). Anal. calcd. for $\mathrm{C}_{208} \mathrm{H}_{272} \mathrm{O}_{16} \mathrm{~N}_{8} \mathrm{Ni}$ : C 77.65, H 8.58, N 3.48; found: C 77.48, H 9.03 N, 3.61 .

\section{Synthesis of nickel $1,2,3,4,8,9,10,11,15,16,17,18$,} 22,23,24,25-hexadeca-(1-adamantaneethoxy)phthalocyanine (19)

3,4,5,6-Tetra-(1-adamantaneethoxy)phthalonitrile $(\mathbf{1 0}, 0.260 \mathrm{~g}$, $0.31 \mathrm{mmol}$ ) and nickel(II) chloride (40 mg, $0.31 \mathrm{mmol}$ ) were added to $4 \mathrm{~mL}$ of DMEA. The mixture was heated to $145^{\circ} \mathrm{C}$ and allowed to stir under argon. After stirring for $24 \mathrm{~h}$, a green solid was precipitated following the addition of $40 \mathrm{~mL}$ of water and was worked up as for 17 . Yield: $32 \%(85 \mathrm{mg})$; $\mathrm{mp}>300{ }^{\circ} \mathrm{C}$. TLC (hexane - ethyl acetate, 9:1): $R_{f} 0.73$. $\mathrm{UV}$-vis (dichloromethane) $\lambda_{\max }(\log \varepsilon)(\mathrm{nm}): 736$ (4.85), 660 (4.25), 372 (4.40), 340 (4.48), 312 (4.61). ${ }^{1} \mathrm{H}$ NMR $\left(\mathrm{CDCl}_{3}\right) \delta: 4.78\left(\mathrm{t}, 16 \mathrm{H}, J=7.1 \mathrm{~Hz}, \mathrm{OCH}_{2} \mathrm{CH}_{2}\right), 4.53(\mathrm{t}$, $\left.16 \mathrm{H}, J=7.1 \mathrm{~Hz}, \mathrm{OCH}_{2} \mathrm{CH}_{2}\right), 2.12(\mathrm{t}, 16 \mathrm{H}, J=7.1 \mathrm{~Hz}$, 
$\mathrm{OCH}_{2} \mathrm{CH}_{2}$ ), 2.05 (two br m, 48H, bridgehead $\mathrm{CH}$ ), 1.94 (t, $\left.16 \mathrm{H}, J=7.1 \mathrm{~Hz}, \mathrm{OCH}_{2} \mathrm{CH}_{2}\right), 1.62-1.85(\mathrm{~m}, 192 \mathrm{H}$, adamantyl- $\mathrm{CH}_{2}$ ). MALDI-MS $\mathrm{m} / \mathrm{z}$ (rel. intensity): $3418[\mathrm{M}$ $+\mathrm{H}]^{+}(83), 3256\left[\mathrm{M}+\mathrm{H}-\mathrm{C}_{12} \mathrm{H}_{19}\right]^{+}(72), 3094[\mathrm{M}+\mathrm{H}-$ $\left.2\left(\mathrm{C}_{12} \mathrm{H}_{19}\right)\right]^{+}(100), 2930\left[\mathrm{M}+\mathrm{H}-3\left(\mathrm{C}_{12} \mathrm{H}_{19}\right)\right]^{+}$(85). Anal. calcd. for $\mathrm{C}_{224} \mathrm{H}_{304} \mathrm{O}_{16} \mathrm{~N}_{8} \mathrm{Ni}$ : C 78.59, $\mathrm{H}$ 8.95, N 3.27; found: C 78.07, H 9.29, N 3.64.

\section{Conclusions}

Phthalocyanines bearing large bulky substituents have previously shown interesting physicochemical properties, including a red shifting of the $Q$ band. A series of metallated and nonmetallated Pcs have been synthesized incorporating large bulky substituents based upon analogs of adamantane. These complexes exhibit interesting characteristics, notably pronounced red shifting of the $\mathrm{Q}$ band.

\section{Acknowledgement}

We thank the Natural Sciences and Engineering Research Council of Canada (NSERC) for grants in support of this research.

\section{References}

1. F.H. Moser and A.L. Thomas. In Phthalocyanine compounds. Reinhold, New York. 1963.

2. C.C. Leznoff and A.B.P. Lever. In Phthalocyanines: properties and applications. Vols. 1-4. Wiley-VCH, New York. 19891996.

3. C. Peichocki, J. Simon, A. Skoulious, D. Guillon, and P. Weber. J. Am. Chem. Soc. 104, 5254 (1982).
4. J.S. Shirk, R.G.F. Pong, H. Heckmann, and M. Hanack. J. Phys. Chem. A, 104, 1438 (2000).

5. I. Rosenthal and E. Ben-Hur. In Phthalocyanines: Properties and applications. Vol. 1. Edited by C.C. Leznoff and A.B.P. Lever. Wiley-VCH, New York. 1989.

6. A.B.P. Lever and C.C. Leznoff. US prov. Patent Appl. 60/474 301, 30 May 2003; A.B.P. Lever and C.C. Leznoff. PCT/CA2004/000808 (WO2004/106436 A1).

7. C.C. Leznoff, S. Black, A. Hiebert, P.W. Causey, D. Christendat, and A.B.P Lever. Inorg. Chim. Acta, 359, 2690 (2006).

8. P.M. Burnham, M.J. Cook, L.A. Gerrard, M.J. Heeney, and D.L. Hughes. Chem Commun. (Cambridge), 2064 (2003).

9. T. Fukuda, K. Ono, S. Homma, and N. Kobayashi. Chem. Lett. 32, 736 (2003); T. Fukuda, T. Ishigura, and N. Kobayashi. Tetrahedron Lett. 46, 2970 (2005).

10. N. Kobayashi. In Phthalocyanines: Properties and applications. Vol 2. Edited by C.C. Leznoff and A.B.P. Lever. Wiley-VCH, New York. 1992.

11. A.K. Sobbi, D. Wohrle, and D. Schlettwein. J. Chem. Soc. Perkin Trans. 2, 481 (1993).

12. P.J. Duggan and P.F. Gordon. Eur. Patent Appl. EP 155780 , 1985.

13. M.J. Cook, A.J. Dunn, S.D. Howe, and A.J. Thomson. J. Chem. Soc. Perkin Trans. 1, 2453 (1998).

14. W. Eberhardt and M. Hanack. Synthesis, 95 (1997).

15. L.V. Gubareva, L. Kaiser, F.G. Hayden. Lancet, 335, 827 (2000).

16. S.M. Antonov, J.W. Johnson, N.Y. Lukomskaya, N.N. Potapyeva, V.E. Gmiro, and L.G. Magazanik. Mol. Pharmacol. 47, 559 (1995).

17. J.J. Wang, Y.C. Chen, C.W. Chi, K.T. Huang, and Y.T. Chern. Anti-Cancer Drugs, 15, 697 (2004).

18. C.C. Leznoff and J.L. Sosa-Sanchez. Chem. Commun. (Cambridge), 338 (2004).

19. N. Bhardwaj, J. Andraos, and C.C. Leznoff. Can. J. Chem. 80, 141 (2002). 